\title{
Dental and Jaws Status in Pre-historic Human Population of the Gomolava Site
}

\author{
Djurica Grga ${ }^{1}$, Ilija Mikić2 , Bogdan Lisul', Tamara Zlopaša3, Bojan Dželetović ${ }^{1}$ \\ 'University of Belgrade, School of Dental Medicine, Department of Restorative Odontology and Endodontics, Belgrade, \\ Serbia; \\ ${ }^{2}$ Institute for Archeology, Serbian Academy of Sciences and Arts, Belgrade, Serbia; \\ "Dental Office "Dr Zlopaša", Belgrade, Serbia
}

\begin{abstract}
SUMMARY
Introduction Knowledge of biological and cultural heritage represents a significant basis for the advance of human civilization. The aim of this study was to determine and define dental health status of pre-historic people of the Vinca culture.

Material and method Study included twenty skeleton remnants of different gender and age from anthropological series of Gomolava. Skeletons originated from one necropolis and two individual graves dating from mid and early Neolithic periods of the Vinca culture. Based on radiocarbon analysis absolute skeletal age was determined to date within the periods from $5848 \pm 38$ to $5739 \pm 35$ BC. Preservation of skeletons varied from completely preserved skulls and jaws to fragmented parts of jaws. Data analysis was performed with methodology used in the research of human population teeth and jaws from the Lepenski Vir culture.

Results Results showed high level of teeth abrasion (98,1\%), medium level of dental calculus deposits (44,9\%), low level of tooth decay, significant number of retained roots, as well as the occurrence of periapical lesions and periodontal disease within the neolith population of Gomolava site.

Conclusion Taking into account absolute age of examined skeletons, collected data are very significant, from the perspective of its wide content. From a pathological perspective, teeth abrasion stands out as a dominant feature, while tooth decay fits within standard values for human population of the neolith period.
\end{abstract}

Keywords: the Vinca culture; Gomolava; teeth; abrasion; tooth decay

\section{INTRODUCTION}

Archaeological site Gomolava is located on the left bank of the river Sava in a wider region of Ruma municipality, the Republic of Serbia (Picture 1). First individual, amateur exploration of this site dates back as far as to the beginning of the $20^{\text {th }}$ century, while first systematic ones were done on two occasions half a century later when larger sites were found and explored (over $3600 \mathrm{~m}^{2}$ ) [1-5]. First phase took place between 1954 and 1957. These explorations found that the site holds a significant cultural layer, which indicates continuity and length of colonisation to this area $[3,4,6]$. Through the second phase which went on for two decades (1965-1985) archaeologists like Brukner, Jovanovic and Tasic defined the stratigraphic site location and determined that the rich cultural layer, which thickness ranges from 5.5 to $6.5 \mathrm{~m}$, contains remains of settlements from seven different cultural periods [1]. Based on material, cultural traces and remains of human skeleton found between the first cultural layer, Gomolava I, originating from late Neolith regarded as the period of Vinca culture, and the last one, Gomolava VII, belonging to the Roman period, there is possibility to explore human activity in a timeframe of over 6000 years [4, 5, 7-11].
Several necropolis and individual graves were found during excavation $[2,5,8,9,12,13]$. Twenty human skeletons found at Gomolava I date back to late Neolith, e.g. the Vinca culture. These are significant and numerous findings with respect to soil characteristics these skeletons were excavated from. It is known that the soil, where skeletons were buried is very aggressive, leading to fast disintegration of biological remains. From this group, physical anthropologist Z. Zoffmann extracted and anthropologically processed fourteen adult skeletons, assorting them to a "very gracile type of atlanto-mediterranean taxons within the Carpathian basin", except two (2/75 \& 16) which she assorted to the Cro-Magnon group. Anthropological analysis determined that the average height of pre-historic habitants of Gomolava ranged from 1576 to $1767 \mathrm{~mm}$. Also, finding of pathological changes on skeletons is very deficient (occasional blow or arthrosis). Regarding dental parameters from that period, a relatively high rate of tooth decay was identified (3.7\%) [12].

The aim of this study was to review and define dental health status of pre-historic people dating from the Vinca culture period, based on the analysis of teeth and jaws of preserved remains of human skeleton skulls from the anthropological group of Gomolava. 


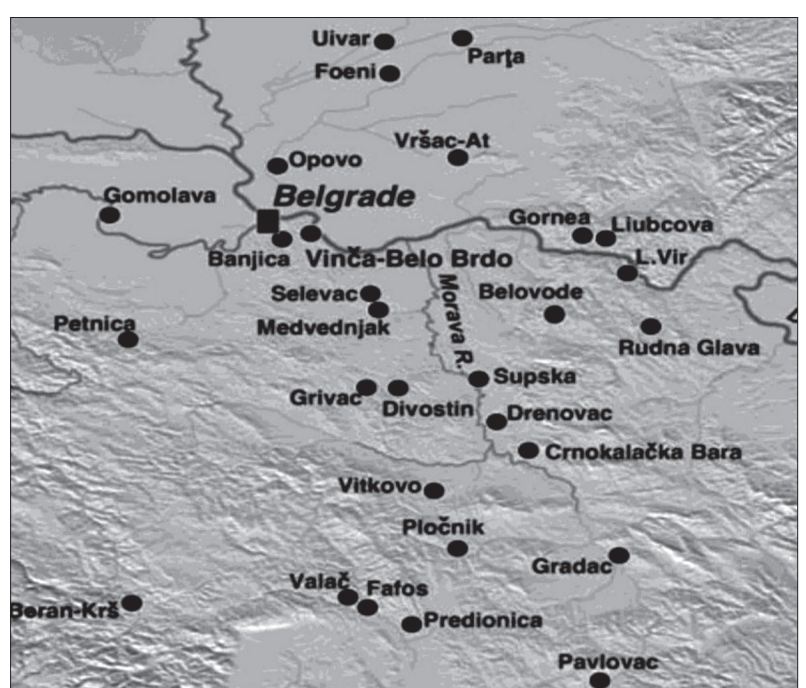

Picture 1. The map of the neolithic sites on the territory of Serbia (Borić D.)

Slika 1. Mapa neolitskih lokaliteta na tlu Srbije (Borić D.)

\section{MATERIAL AND METHOD}

Study included twenty skeleton remains of different gender and age. Skeletons originated from one necropolis and two individual graves dating from mid and early Neolithic periods of the Vinca culture (Picture 2). Based on radiocarbon analysis absolute skeletal age was determined to date within the periods from $5848 \pm 38$ to $5739 \pm 35 \mathrm{BC}$ $[10,11,14]$. Preservation of skeletons varied from completely preserved skulls and jaws to fragmented parts of jaws. Data analysis was performed with the methodology used in the research of human population teeth and jaws from the Lepenski Vir culture [15, 16, 17]. Table for basic information data included: skeleton number, individuals' age and gender (data taken from previously published anthropological analysis). In the Table for jaws preservation assessment number 1 stands for complete preservation, 0.5 for partial and 0 for the absence of examined jaw segment. Tables for lower and upper jaw generate a wide range of data ( 7 columns and 16 rows). First column shows data on dentition type. Second column generates information on teeth status and consists of 6 types of data: 1 - present tooth, 2 - tooth lost during lifetime, 3 - tooth lost after death, 4 - present tooth root, 5 - tooth root lost after death, 6 - tooth germ. Third column shows data on tooth surfaces affected with tooth decay numerically defined on a 1-5 scale, (1 - occlusal and incisal, 2 - mesial, 3 - distal, 4 - vestibular, 5 - oral). Fourth column consists of data assessing tooth decay depth and it is numerated 1-4, (1 - superficial, 2 - medium and deep, 3 - dental cavity trepanation, 4 - radix). Data on teeth abrasion were summerized up in the fifth table and expressed on a 0-4 scale ( 0 - tooth without abrasion, 1 - enamel abrasion, 2 - dentin abrasion, 3 - abrasion with dental cavity trepanation, 4 - radix). Sixth column shows data on existing levels of tooth tartar on a 0-3 scale, ( 0 - without tartar, $1-1 / 3$ of tooth covered by tartar, $2-2 / 3$ of tooth covered by tartar, 3 - tooth completely covered by tartar). Seventh column generates data on existing macroscopically visible

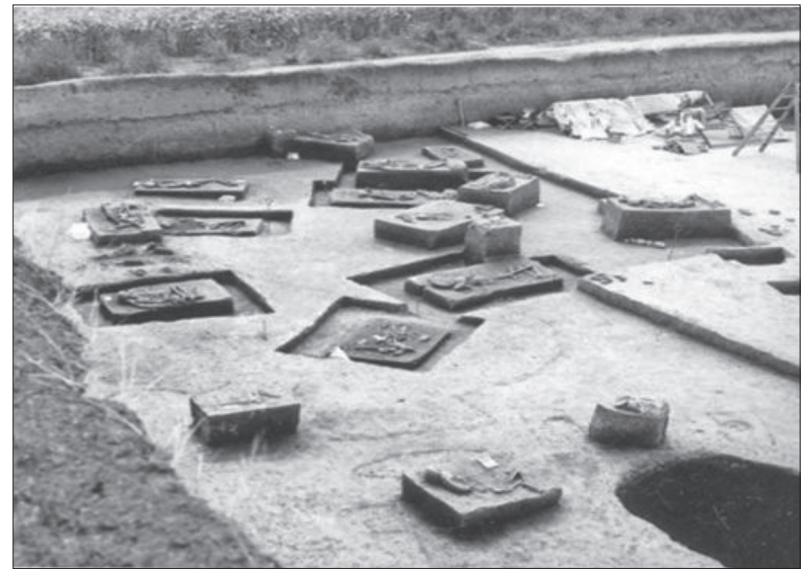

Picture 2. Original photo of the necropola from the Gomolava archeological site (exhibition of the Museum of Vojvodina Novi Sad) Slika 2. Originalna fotografija nekropole sa lokaliteta Gomolava (postavka Vojvođanskog muzeja Novi Sad)

periapical lesions $(0-$ not present, $1-\leq 5 \mathrm{~mm}$ in diameter, $2->5 \mathrm{~mm}$ in diameter).

Ordinary number of teeth $[17,18,19]$ defined the number of rows in each of the two tables. All eventual findings on exceeded number of teeth were stated as anomalies in the space for additional comments.

\section{RESULTS AND DISCUSSION}

It was established after dental examination that there is not enough dental status data for the three individuals from graves 8,14 and 15 , and that the skeleton number 13 was on the display "in sittu" as a permanent museum exponent and not available for analysis. Therefore, the total number of samples included in this study was 16 skeletons, two children and 14 aduls. Adult group consisted of 13 male and 1 female individual.

Oral status of 14 adult individuals is shown in Table 1. There were 256 present teeth, 28 have been lost during lifetime and 79 lost after death during excavation or storing in the museum collection. There were 28 tooth roots found due to pathological processes that occurred during life. It was found with high certainty, that for 6 teeth, roots existed in the moment of death that indicated their loss after death. Through macroscopic analysis data was gathered on 406 teeth in total.

Knowing that both aforementioned taxons that examined skeletons belong to have number of teeth and teeth formula similar to present-day humans (32 teeth: 8 incisors, 4 canines, 8 premolars and 12 molars), it can be said that the status of $90 \%$ of teeth was defined within this study, with respect to the initial assumption that ideally (completely preserved dentition) there would be a sample of 448 teeth present (14x32).

Beside aforementioned, it is also possible to add results on data from another 11 molars (5 upper and 6 lower), representing $2.9 \%$ of all teeth. It was determined with high certainty these teeth did not erupt before the mo- 
Table 1. Oral status of adult individuals from neolith necropolis of Gomolava site

Tabela 1. Oralni status odraslih osoba iz neolitske nekropole sa lokaliteta Gomolava

\begin{tabular}{|l|c|c|c|c|c|c|c|c|c|c|c|c|}
\hline \multicolumn{10}{|c|}{$\begin{array}{l}\text { Maxilla and mandible - adults } \\
\text { Maksila i mandibula - odrasle osobe }\end{array}$} \\
\hline $\begin{array}{l}\text { Type } \\
\text { Tip }\end{array}$ & ST. & ST \% & K.Pov. & K.Pov \% & K.D. & K.D.\% & Abr. & Abr. \% & Kam. & Kam. \% & A.Par. & A.Par \% \\
\hline 1 & 265 & $65.27 \%$ & 2 & $0.75 \%$ & 2 & $0.75 \%$ & 42 & $15.85 \%$ & 106 & $40.00 \%$ & 9 & $3.40 \%$ \\
\hline 2 & 28 & $6.90 \%$ & 1 & $0.38 \%$ & 1 & $0.38 \%$ & 137 & $51.70 \%$ & 12 & $4.53 \%$ & 2 & $0.75 \%$ \\
\hline 3 & 79 & $19.46 \%$ & 1 & $0.38 \%$ & 1 & $0.38 \%$ & 43 & $16.23 \%$ & 1 & $0.38 \%$ & 0 & $0.00 \%$ \\
\hline 4 & 28 & $6.90 \%$ & 0 & $0.00 \%$ & 0 & $0.00 \%$ & 38 & $14.34 \%$ & 0 & $0.00 \%$ & 0 & $0.00 \%$ \\
\hline 5 & 6 & $1.48 \%$ & 0 & $0.00 \%$ & 0 & $0.00 \%$ & 0 & $0.00 \%$ & 0 & $0.00 \%$ & 0 & $0.00 \%$ \\
\hline 6 & 0 & $0.00 \%$ & 0 & $0.00 \%$ & 0 & $0.00 \%$ & 0 & $0.00 \%$ & 0 & $0.00 \%$ & 0 & $0.00 \%$ \\
\hline $\begin{array}{l}\text { Total } \\
\text { Suma }\end{array}$ & 406 & $100.00 \%$ & 4 & $1.51 \%$ & 4 & $1.51 \%$ & 260 & $98.11 \%$ & 119 & $44.91 \%$ & 11 & $4.15 \%$ \\
\hline
\end{tabular}

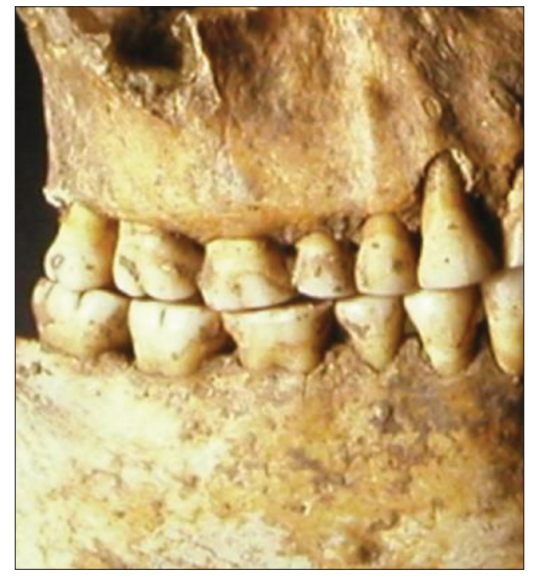

Picture 3. Tooth abrasion

Slika 3. Abrazija zuba

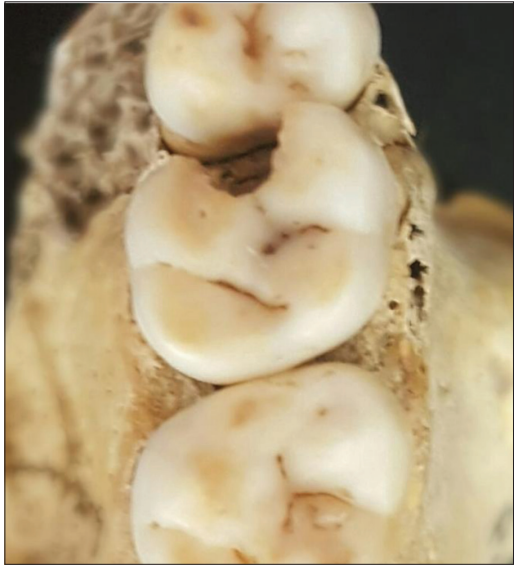

Picture 4. Class II decay

Slika 4. Karijes II klase

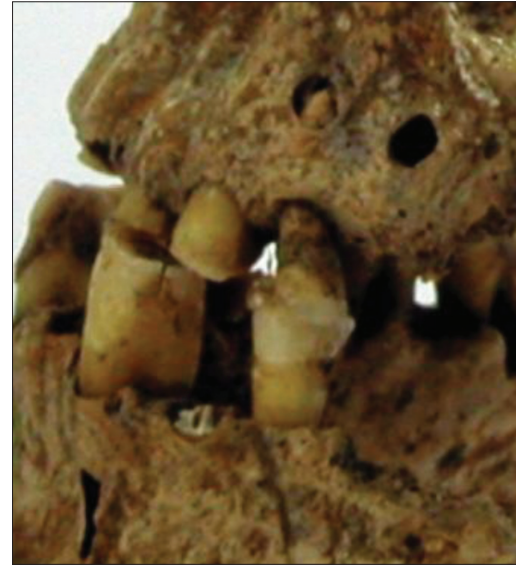

Picture 5. Periapical lesions above the remaining tooth roots

Slika 5. Periapikalne lezije iznad zaostalih korenova ment of death of an individual. It's valid to assume that in one sample (skeleton number 17) all four third molars were missing, due to the fact that the individual was less than 17 years old at the moment of death. Other seven third molars were probably left impacted because of their belonging to already mature individuals with formed dentition at the moment of death.

For the 29 teeth left (6.5\%) it was not possible to collect data due to partial or complete devastation of jaws. In one case (skeleton number 13) maxillofacial segment was not complete, lacking the lower jaw with all 16 teeth (3.6\%).

Optimal number of 448 teeth, which theoretically could have been present in all adult individuals at the moment of death, lacks another 13 teeth $(2.9 \%)$ as it was not possible to determine their status due to skeletal devastation and loss of alveolar bone.

Teeth abrasion was dominant pathological finding in this neolith group. From 265 present teeth, this pathological process was found on 260 of them (98.1\%). Different levels of tooth wearing were present. Most common was level 2 abrasion present on 137 (51.7\%) of the total number of present teeth (Picture 3). There was similar number of teeth found with level 3 - 43 teeth (16.2\%) and level 1 abrasion -42 teeth (15.9\%). The most severe case of abrasion (level 4) with certain dental cavity trepanation and total crown loss was identified on 38 teeth (14.3\%). Similar findings for the neolith culture of Lepenski Vir were significantly lower, indicating that slightly more than half of total number of teeth was exposed to some level of abrasion (55\%) [16]. Apart from that, abrasion was an eminent occurrence for all human populations of mesolith and neolith. Explanation to such tooth wear in the neolith population of Gomolava, can be found in the fact that 13 of 14 examined skeletons (93\%) belong to mature and senile life chapters, meaning these individuals were in their fifth, sixth or seventh life decade at the moment of death.

Three male individuals belonging to mature age category were identified to have tooth decay. Tooth decay was found on $5(1.9 \%)$ of the total number of present teeth. Two lower incisors of the same skeleton were affected by tooth decay level 2 on their facing proximal surfaces. On the upper jaw of the same skeleton, level 1 tooth decay was identified on the occlusal surface of second molar. Other two teeth with decay were found on different skeletons. Both developed on molars. One affected two surfaces reaching as far as dentin (Picture 4) and the other one developed over three surfaces, causing dental cavity trepanation (level 3).

Dental calculus deposits were identified on 119 present teeth (44.9\%). Most of them were level 1 deposit on 106 teeth $(89 \%)$. One tooth was completely covered by calculus (level 3).

Due to resorption and perforation of alveolar bone during life, or devastation of porous bone under grave soil, it was sometimes possible to macroscopically detect 
Table 2. Dental status of childhood individuals from neolith necropolis of Gomolava site Tabela 2. Status zuba u dečjem uzrastu iz neolitske nekropole sa lokaliteta Gomolava

\begin{tabular}{|l|c|c|c|c|c|c|c|}
\hline $\begin{array}{l}\text { Skeletal } \\
\text { number } \\
\text { Red. br. } \\
\text { skeleta }\end{array}$ & $\begin{array}{c}\text { Permanent } \\
\text { teeth } \\
\text { Stalni zubi }\end{array}$ & $\begin{array}{c}\text { Lost teeth } \\
\text { during lifetime } \\
\text { Izgubljeni } \\
\text { tokom života }\end{array}$ & $\begin{array}{c}\text { Lost teeth after } \\
\text { death } \\
\text { Izgubljeni posle } \\
\text { smrti }\end{array}$ & $\begin{array}{c}\text { Lost teeth } \\
\text { Primary teeth } \\
\text { Mlečni zubi } \\
\text { during lifetime } \\
\text { Izgubljeni } \\
\text { tokom života }\end{array}$ & $\begin{array}{c}\text { Lost teeth } \\
\text { after death } \\
\text { Izgubljeni } \\
\text { posle smrti }\end{array}$ & $\begin{array}{c}\text { Permanent } \\
\text { teeth buds } \\
\text { Zametak } \\
\text { stalnih zuba }\end{array}$ & $\begin{array}{c}\text { Total } \\
\text { Ukupno }\end{array}$ \\
\hline 4 & 9 & 0 & 3 & 10 & 0 & 2 & 2 \\
\hline 8 & 7 & 0 & 4 & 9 & 1 & 2 & 2 \\
\hline $\begin{array}{l}\text { Total } \\
\text { Ukupno }\end{array}$ & 16 & 0 & 7 & 19 & 1 & 5 & 5 \\
\hline
\end{tabular}

Table 3. Oral status of childhood individuals from neolith necropolis of Gomolava site

Tabela 3. Oralni status osoba dečjeg uzrasta iz neolitske nekropole sa lokaliteta Gomolava

\begin{tabular}{|c|c|c|c|c|c|c|c|c|c|c|c|c|}
\hline \multicolumn{13}{|c|}{$\begin{array}{l}\text { Maxilla and mandible - children } \\
\text { Maksila i mandibula - deca }\end{array}$} \\
\hline $\begin{array}{l}\text { Type } \\
\text { Tip }\end{array}$ & ST. & ST \% & K.Pov. & K.Pov \% & K.D. & K.D.\% & Abr. & Abr. \% & Kam. & Kam. \% & A.Par. & A.Par \% \\
\hline 1 & 35 & $70.00 \%$ & 0 & $0.00 \%$ & 0 & 0 & 5 & $14.29 \%$ & 0 & 0 & 0 & 0 \\
\hline 2 & 1 & $2.00 \%$ & 4 & $11.43 \%$ & 4 & $11.43 \%$ & 4 & $11.43 \%$ & 0 & 0 & 0 & 0 \\
\hline 3 & 12 & $24.00 \%$ & 0 & $0.00 \%$ & 0 & 0 & 0 & $0.00 \%$ & 0 & 0 & 0 & 0 \\
\hline 4 & 0 & $0.00 \%$ & 0 & $0.00 \%$ & 0 & 0 & 0 & $0.00 \%$ & 0 & 0 & 0 & 0 \\
\hline 5 & 0 & $0.00 \%$ & 0 & $0.00 \%$ & 0 & 0 & 0 & $0.00 \%$ & 0 & 0 & 0 & 0 \\
\hline 6 & 2 & $4.00 \%$ & 0 & $0.00 \%$ & 0 & 0 & 0 & $0.00 \%$ & 0 & 0 & 0 & 0 \\
\hline $\begin{array}{l}\text { Total } \\
\text { Suma }\end{array}$ & 50 & $100.00 \%$ & 4 & $11.43 \%$ & 0 & 0 & 9 & $25.71 \%$ & 0 & 0 & 0 & 0 \\
\hline
\end{tabular}

periapical changes on teeth. This study examined and identified such lesions in 12 cases. In 10 cases the extent of the lesion was level 1, and in other two level 2 lesions were found (Picture 5).

Changes to the alveolar bone were also found on some of the skeletal remains of human populations of Gomolava site, which indicated the presence of periodontal disease. Eight persons had alveolar bone resorption and roots exposed in the level of their furcation. These resorptions ranged from 3 to $7 \mathrm{~mm}$.

This study also showed two significant findings on tooth roots status. The first one was the number of roots present (28), which was relatively high and equal to the number of teeth lost during life, especially when there are 6 samples of shallow and non-healed alveolus indicating roots came out just before, or more probably after death. Second one shows tooth crowns were completely devastated under some pathological process or trauma during life. It was not rare to detect periapical processes around tooth roots. Analysis of this osteological material showed the presence of 28 tooth roots within jaws of 8 individuals, as well as another 6 cases where root was lost after death. In the apical area of identified roots 5 periapical lesions were registered (four level 1 and one level 2). Etiological factor for this pathological occurrence on 31 teeth was most probably abrasion. Tooth decay was not present on other teeth, while surrounding ones had level 3 and level 4 abrasions. In three cases loss of tooth crown could be assigned to tooth decay, because other teeth are preserved, with low-level abrasion. In that case, percentage of tooth decay for the Gomolava human population would rise from 1.95 to $3 \%$, which is still lower than the values determined by Zofmann [12]. In her studies tooth decay was found in $3.7 \%$ of cases that is significantly higher than average values for that period. Regarding tooth decay, it's incidence during neolith on the territory of modern $\mathrm{Eu}-$ rope varied from $1.4 \%$ to $3.2 \%$ and that is in accordance with findings of the current study for the Gomolava site. Analysis of teeth from skeletons in the Iron Gate series from the territory of Iron Gate (modern day Serbia) found that tooth decay affected $1.28 \%$ teeth of $3.76 \%$ individuals from the neolith culture of Lepenski Vir [15, 17, 19-22].

Child skeletons belonged to the infants II age group, being at the time of death between 6-8 years of age, with presence of mixed dentition. It was concluded that the data in this study showed information on primary dentition and positions of first and second permanent molars and incisors. Permanent dentition of both individuals consisted of four first molars and two second molar germs in the upper jaw of one individual. Permanent dentition also included 8 incisors (5 upper and 3 lower). It was found that at the moment of death, additional seven permanent teeth were present, probably lost during excavation or storing. All permanent teeth were healthy, without any present tooth decay, abrasion, deposits, anomalies or periodontal changes (Table 2).

Primary dentition had 19 teeth present (47\%) mostly molars (16) and canines (3). Remaining three canines were lost after death; one primary incisor was lost during life confirmed by the presence of agnate alveolus. One person was identified with class II tooth decay, which developed over occlusal and proximal surfaces of all four upper molars. Nine primary teeth were affected with abrasion (five level 1, four level 2). Deposits on teeth, tooth and jaw anomalies as well as changes on the periodontal tissues were not detected (Table 3).

This study showed with high certainty that after eight millenniums two children from the period of the Vinca culture, had completely preserved dentition that suits their age at the time of their death. Their skeletal remains showed they had all primary molars and canines, four permanent molars both, one primary and 15 permanent 
incisors with one primary incisor being lost during life. Level 1 and level 2 abrasions were present on primary teeth, and in one case four teeth of class II level 2 tooth decay (caries media).

\section{CONCLUSION}

Taking into account the absolute age of examined skeletons, collected data are very significant, from the perspective of its wide content. Almost 8 millenniums ago human population had two dentitions. Tooth abrasion was dominant feature detected on most permanent teeth. In childhood it appeared in mixed dentition on primary teeth. Tooth decay affected both permanent and primary teeth, in low percentage, as typical for that period. Dental calculus was identified on almost half of teeth present. Signs of periodontal disease and periapical lesions were found.

\section{ACKNOWLEDGEMENT}

Courtesy of academics Bogdan Brukner and Borislav Jovanovic enabled us insight into the structure and documentation for this work, for which we express our deepest respect and gratitude.

\section{REFERENCES}

1. Brukner R, Jovanović B, Tasić N. Praistorija Vojvodine. Novi Sad: Institut za izučavanje istorije Vojvodine: Savez arheoloških društava Jugoslavije; 1974 (Monumenta archaeologica; 1).

2. Srejović D, urednik. Arheološki leksikon: preistorija Evrope, Afrike i Bliskog istoka, grčka, etrurska i rimska civilizacija. Beograd: Savremena administracija; 1997. str. 322.

3. Rašajski R. Gomolava kod Hrtkovaca: rezultati probnih istraživanja. Rad vojvođanskih muzeja. 1954; 3:187-219.

4. Girić M. Istorijat dosadašnjih iskopavanja na Gomolavi. Rad vojvođanskih muzeja. 1965; 14:109-11.

5. Garašanin M. Praistorija na tlu Srbije. Beograd: Srpska književna zadruga; 1973.
6. Milutin Garašanin. Centralnobalkanska zona. U: A. Benac. Praistorija Jugoslovenskih zemalja-neolit. Sarajevo: Akademija nauka i umjetnosti BiH; 1979. str. 79-212.

7. Brukner B. Naselje vinčanske grupe na Gomolavi. Rad vojvođanskih muzeja. 1980; 26:5-55.

8. Tasić N. The Early Iron Collective tomb of Gomolava. Archeologia lugoslavica. 1972; XIII:27-39.

9. Jovanović B, Jovanović M, Borojević K, Popović P, Stančić V, Zoffmann ZK, i dr. Gomolava: naselje mlađeg gvozdenog doba. Novi Sad: Vojvođanski muzej; Beograd: Arheološki institut; 1988.

10. Borić D. The end of the Vinca world: Modelling the Neolithic to Copper Age transition and the notion of archaeological culture. In: Hansen S, Raczky P, Anders A, Reingruber A, eds. Neolithic and Copper Age Between the Carpathians and the Aegean Sea: Chronologies and Technologies from the 6th to 4th Millennia BCE, Archaologie In Eurasien, vol. 31. Bonn: Verlag Marie Leidorf; 2015. p. 157-217.

11. Borić $D$. Absolute dating of metallurgical innovations in the Vinča Culture of the Balkans. In: Kienlin TL and Roberts Ben W, eds. Metals and Societies: Studies in honour of Barbara S. Ottaway, Universitätsforschungen zur prähistorischen Archäologie, vol. 169. Bonn: Habelt; 2009. p. 191-245.

12. Zoffmann ZK. Das anthropologische material des spätneolitischen gräberfeldes von Hrtkovci - Gomolava. Rad vojvođanskih muzeja. 1987; 30:43-69

13. Mikić Ž. Antropološka struktura stanovništva Srbije. Beograd: Odeljenje za etnologiju Filozofskog fakulteta; 1988.

14. Borić D. Mortuary practices, bodies and persons in the Neolithic and Early-Middle Copper Age of Southeast Europe. In: Fowler C, Harding I and Hofmann D, eds. The Oxford Handbook of Neolithic Europe, Oxford Handbooks. Oxford: Oxford University Press; 2015. p. $927-58$.

15. Grga Đ. Abrazija zuba kao obeležje humane populacije kulture Lepenskog vira. Balcanica. 1997; XXVIII:79-94.

16. Grga Đ. Najstariji tragovi karijesa na tlu današnje Jugoslavije. Stomatološki glasnik Srbije. 1997; 37.

17. Grga $\bigoplus$. Tooth abrasion among the prehistoric population of the Iron Gate culture. Balkan Journal of Stomatology. 1998; 2:92-7.

18. Hilson S. Dental Anthropology. Cambridge: University Press; 1996.

19. Brothwell DR. Dental Anthropology. Oxford: Pergamon Press; 1963.

20. Grga Đ. Karijes u humanoj populaciji kulture Lepenskog vira. Starinar. 1996; XLVII:177-85.

21. Đurić Srejić M. Uvod u antropologiju drevnih populacija. Beograd: Zavod za udžbenike i nastavna sredstva; 1995. str. 261-85.

22. Živanović S. Vinča Skeletons Studied in situ at the Gomolava Site, Yugoslavia. Current Anthropology. 1977; 18:533-4. 


\title{
Status zuba i vilica praistorijske humane populacije sa lokaliteta Gomolava
}

\author{
Đurica Grga', Ilija Mikić2 , Bogdan Lisul', Tamara Zlopaša³, Bojan Dželetović ${ }^{1}$ \\ 'Univerzitet u Beogradu, Stomatološki fakultet, Klinika za bolesti zuba, Beograd, Srbija; \\ ${ }^{2}$ Arheološki institut Beograd, Srbija; \\ ${ }^{3}$ Stomatološka ordinacija „Dr Zlopaša“, Beograd, Srbija
}

\begin{abstract}
KRATAK SADRŽAJ
Uvod Poznavanje biološkog i kulturnog nasleđa je bitna pretpostavka daljeg civilizacijskog napretka. Cilj ovog rada je bio da se na osnovu očuvanih humanih skeletnih ostataka lobanja i vilica antropološke serije sa Gomolave, analizom zuba i vilica, sagleda i definiše zubno-zdravstveni status praistorijskih ljudi iz perioda Vinčanske kulture.

Materijal i metod Istraživanja su obuhvatila dvadeset skeletnih ostataka, različitog pola i individualne starosti. Skeleti potiču iz jedne nekropole i dva pojedinačna groba srednjeg i mlađeg neolita iz perioda Vinčanske kulture. Apsolutna starost skeleta je radiokarbonskom analizom ugljenika C14 datovana u periodu od 5848. \pm 38 do 5739 . \pm 35 godina pre nove ere. Očuvanost skeleta je bila različita i kretala se od kompletno sačuvanih lobanja i vilica do fragmentovanih delova vilica. Podaci su analizirani metodologijom koja je primenjivana u istraživanjima zuba i vilica humane populacije Kulture Lepenskog Vira.

Rezultati Rezultati su ukazali na visok stepen abrazije zuba (98.1\%) neolitske populacije sa lokaliteta Gomolava, umereni stepen naslaga (44,9\%), nizak stepen karijesa, značajan broj zaostalih korenova, kao i pojavu periapikalnih procesa i parodontopatije.

Zaključak Uzimajući u obzir apsolutnu starost ispitivanih skeleta, prikupljeni podaci su izuzetno vredni po obimu građe i njenom sadržaju. Patološkom slikom dominira abrazija, dok je karijes prisutan u okviru standardnih vrednosti za humanu populaciju iz perioda neolita.
\end{abstract}

Ključne reči: Vinčanska kultura; Gomolava; zubi; abrazija; karijes

\section{UVOD}

Arheološki lokalitet Gomolava nalazi se na levoj obali reke Save u širem regionu grada Rume u Republici Srbiji (Slika 1). Prva pojedinačna, amaterska istraživanja ovog lokaliteta datiraju još sa početka 20. veka, a sistematskim istraživanjima se pristupilo pola veka kasnije kada su u dva navrata otkrivene i istražene velike površine (preko $3.600 \mathrm{~m}^{2}$ ) [1-5]. Prva faza se odvijala od 1954. do 1957. godine, a istraživanja su otkrila da lokalitet sadrži značajan kulturni sloj koji ukazuje na kontinuitet i dužinu naseljavanja ovog prostora $[3,4,6]$. U drugoj fazi, koja je trajala dve decenije (1965-1985), istraživači poput Bruknera, Jovanovića, Tasića definisali su stratigrafski položaj lokaliteta i utvrdili da u veoma moćnom kulturnom sloju, čija se debljina kretala u rasponu od 5,5 do 6,5 metara, postoje ostaci naselja čak sedam različitih kulturnih perioda [1]. Između prvog kulturnog sloja, Gomolava I, koji potiče iz kasnog neolita, odnosno perioda Vinčanske kulture, i poslednjeg, Gomolava VII, koji pripada rimskom periodu, postoje tragovi materijalne kulture i ostaci humanih skeleta, na osnovu kojih se može pratiti kontinuitet života u vremenskom rasponu od preko 6.000 godina $[4,5,7-11]$. Tokom iskopavanja otkriveno je više nekropola i pojedinačnih grobova $[2,5,8,9,12,13]$. Dvadeset skeleta pronađenih $\mathrm{u}$ horizontu Gomolava I datovano je u period kasnog neolita, odnosno Vinčanske kulture. Ovo je izuzetno značajan i brojan nalaz s obzirom na osobine tla u kome su skeleti pronađeni. Poznato je da je zemljište u kome su skeleti sahranjeni veoma agresivno i da dovodi do brze dezintegracije bioloških ostataka. Iz ove grupe fizički antropolog Z. Zoffmann je izdvojila i antropološki obradila četrnaest skeleta odraslih osoba koje je svrstala u ,jednu gracilnu varijantu atlantomediteranskih taksona u Karpatskom basenu", sem dva skeleta (2/75 i 16) koja je opredelila u Kromanjonsku grupu. Antropološkom analizom je ustanovljeno da se prosečna visina praistorijskih stanovnika Gomolave kretala u rasponu od 1.576 do $1.767 \mathrm{~mm}$, kao i da je nalaz patoloških promena na skeletima veoma oskudan (poneki udarac ili artroza). Od stomatoloških parametara, konstatovana je relativno visoka stopa karijesa za taj period $(3,7 \%)[12]$.

Cilj ovog rada je bio da se na osnovu očuvanih humanih skeletnih ostataka lobanja i vilica antropološke serije sa Gomolave, analizom zuba i vilica sagleda i definiše zubno-zdravstveni status praistoriskih ljudi iz perioda Vinčanske kulture.

\section{MATERIJAL I METOD RADA}

Istraživanja su obuhvatila dvadeset skeletnih ostataka, različitog pola i individualne starosti. Skeleti potiču iz jedne nekropole, i dva pojedinačna groba srednjeg i mlađeg neolita iz perioda Vinčanske kulture (Slika 2). Apsolutna starost skeleta je radiokarbonskom analizom ugljenika C14 datovana u period od 5848. \pm 38 do $5739 . \pm 35$ godine pre nove ere $[10,11,14]$. Očuvanost skeleta je bila različita i kretala se od kompletno sačuvanih lobanja i vilica do fragmentovanih delova vilica.

Podaci su analizirani metodologijom koja je primenjivana $\mathrm{u}$ istraživanjima zuba i vilica humane populacije Kulture Lepenskog Vira $[15,16,17]$. U tabeli za osnovne podatke generisani su: broj skeleta, individualna starost i pol individue (podaci preuzeti iz prethodno obavljenih antropoloških analiza). U tabeli za procenu očuvanosti vilica brojem 1 označavano je kompletno prisustvo ispitivanog dela vilice, sa 0,5 delimično, a 0 je označavala odsustvo tog dela. Tabele za donju i gornju vilicu generišu veliki broj podataka (sedam kolona i 16 redova). Prva kolona sadrži podatake o vrsti denticije. Druga kolona generiše podatke o statusu zuba i ona sadrži šest vrsta podataka: 1 - prisutan zub, 2 - izgubljen tokom života, 3 - izgubljen posle smrti, 4 - prisutan koren zuba, 5 - koren zuba izgubljen posle smrti, 
6 - zametak zuba. U treću su unošeni podaci o površinama zuba zahvaćenih karijesom, i definisana je numerički od 1 do $5 \mathrm{u}$ skladu sa brojem površina zuba (1 - okluzalno i incizalno, 2 - mezijalno, 3 - distalno, 4 - vestibularno, 5 - oralno). Četvrta kolona sadrži ocenu dubine karijesa i kreće se od 1 do 4 (1 superficijalis, 2 - medija i profunda, 3 - trepanacija kavuma dentis, 4 - radiks). Podaci o abraziji zuba su unošeni u petu kolonu i stepenovani od 0 do 4 ( 0 - zub bez abrazije, 1 - abrazija gleđi, 2 - abrazija dentina, 3 - abrazija sa trepanacijom kavuma dentis i 4 - radiks). Šesta kolona sadrži podatke o prisustvu čvrstih zubnih naslaga kroz četiri stepena ( 0 - bez naslaga, 1 prekrivena $1 / 3$ zuba, 2 - prekrivene $2 / 3$ i 3 - prekriven ceo zub). Kolona 8 generiše podatke o prisustvu makroskopski vidljivih periapikalnih lezija (0 - nema, 1 - do $5 \mathrm{~mm}$ u prečniku, 2 preko $5 \mathrm{~mm}$ u prečniku).

Uobičajen broj zuba $[17,18,19]$ definisao je i broj redova u svakoj od ove dve tabele. Svi eventualni nalazi o prekobrojnim zubima unošeni su kao konstantovane anomalije u prostor za posebne napomene.

\section{REZULTATI I DISKUSIJA}

Posle obavljenih stomatoloških pregleda ustanovljeno je da za tri individue iz grobova 8, 14 i 15 nema dovoljno stomatoloških podataka, a da je skelet br. 13 izložen in situ kao stalni muzejski eksponat, nedostupan za analizu, tako da je ukupan uzorak obuhvaćen ovom studijom iznosio 16 skeleta. Od toga, dva skeleta su pripadala dečjem uzrastu, a 14 odraslim osobama. U grupi odraslih 13 je bilo muškog, a jedan ženskog pola.

Kod 14 odraslih osoba ustanovljen je sledeći stomatološki status (Tabela 1): prisutno je bilo 265 zuba, izgubljeno u toku života 28, dok je 79 zuba izgubljeno posle smrti osobe, tokom iskopavanja ili čuvanja u zbirci muzeja. Očuvanih korenova zuba nastalih usled patoloških procesa bilo je 28, a za šest zuba je pouzdano ustanovljeno da su korenovi bili prisutni u trenutku smrti, odnosno da su izgubljeni posle egzitusa individue. Sumarno posmatrano, makroskopskom analizom dobijeni su podaci za 406 zuba.

S obzirom na to da oba pomenuta taksona kojima pripadaju ispitivani skeleti imaju broj i formulu zuba sličnu savremenom čoveku (32 zuba: osam inciziva, četiri očnjaka, osam premolara i 12 molara), može se reći da je ovim istraživanjima definisan status preko $90 \%$ zuba, uz početnu pretpostavka da bi se u idealnim uslovima sa kompletnim zubnim nizovima mogao očekivati uzorak od 448 zuba $(14 \times 32)$.

Pored navedenog, ovim rezultatima se mogu priključiti i podaci o još 11 trećih molara (pet gornjih i šest donjih), ili 2,9\% svih zuba, za koje je pouzdano utvrđeno da do trenutka smrti osobe nije izniklo. Opravdano je pretpostaviti da jednoj osobi (skelet br. 17) nedostaju sva četiri umnjaka, zbog uzrasta u kom se nalazila - u trenutku smrti bila je mlađa od 17 godina. Ostalih sedam umnjaka je najverovatnije ostalo inpaktirano, jer su u pitanju osobe koje su u trenutku smrti bile u zreloj životnoj dobi, sa formiranim zubnim nizovima.

Za preostalih 29 zuba (6,5\%) nije bilo moguće prikupiti podatke zbog delimične devastiranosti ili kompletnog gubitka viličnih kostiju. U jednom slučaju (skelet br. 13) maksilofacijalni segment nije bio kompletan, pošto je nedostajala mandibula sa svih 16 zuba (3,6\%).
Do optimalnog broja od 448 zuba, koje su teoretski mogle imati ove odrasle osobe u trenutku smrti, nedostaje još 13 zuba (2,9\%), za koje nije bilo moguće utvrditi status, usled devastiranosti skeleta i gubitka alveolarne kosti.

Proces abrazije je dominantna patološka pojava i u ovoj grupi skeleta iz perioda neolita. Od 265 prisutnih zuba na 260 $(98,1 \%)$ uočava se ovaj patološki proces. Trošenje zuba je bilo različitog stepena. Najčešće je bila prisutna abrazija 2. stepena i to kod 137 zuba $(51,7 \%)$ od svih prisutnih zuba (Slika 3). Približne vrednosti su ustanovljene za abraziju 3. stepena, kojom je zahvaćeno 43 zuba $(16,2 \%)$ i abraziju 1. stepena, kojom je bilo zahvaćeno 42 zuba (15,9\%). Najteži oblik abrazije (4. stepen), uz obavezno otvaranje komore pulpe i gubitak kompletne krunice, uočen je na 38 zuba (14,3\%). Nalazi za neolitski deo Kulture Lepenskog Vira su znatno nižih vrednosti i ukazuju da je tek nešto više od polovine zuba bilo zahvaćeno nekim stepenom abrazije (55\%) [16]. Inače, abrazija je imanentna pojava za sve humane populacije mezolita i neolita. Objašnjenje ovako velikog trošenja zuba u neolitskoj humanoj populaciji sa lokaliteta Gomolava leži u činjenici da od 14 istraženih skeleta 13 (93\%) pripada životnoj dobi maturus i senilis, odnosno da su se osobe $\mathrm{u}$ trenutku smrti nalazile u starijem životnom dobu, odnosno u petoj, šestoj ili sedmoj deceniji života.

Karijes je otkriven kod tri osobe muškog pola, koje su svrstane u starosnu kategoriju maturus. Karijes se razvio na pet zuba (1,9\%) od svih prisutnih zuba. Kod dva donja sekutića, na istom skeletu, zahvaćena je po jedna naspramna aproksimalna površina sa dubinom 2. stepena. Na istom skeletu u maksili je, na drugom molaru, otkriven karijes 1 . stepena na okluzalnoj površini. Preostala dva zuba sa karijesom otkrivena su na različitim skeletima. Oba su se razvila na molarima. Jedan je zahvatio dve površine sa prodorom u dentin (Slika 4), a drugi se proširio na tri površine, i pri tome razorio zub uz trepanaciju komore pulpe (3. stepena).

Naslage na zubima u vidu zubnog kamenca konstatovane su na 119 prisutnih zuba (44,9\%). Najviše zuba je bilo sa naslagama 1. stepena - 106 ( 89\%). Uočen je jedan zub 3. stepena, koji je u potpunosti bio prekriven kamencem.

Zbog resorpcije i perforacije alveolarne kosti tokom života, ili usled brže devastacije poroznije kosti tokom boravka u zemlji, nekada je moguće makroskopski uočiti periapeksne promene na zubima. Ovim istraživanjem su uočene takve promene u 12 slučajeva. Veličina lezija u deset slučajeva je bila 1. stepena, a u dva slučaja uočene lezije su svrstane u 2. stepen (Slika 5).

Na skeletnim ostacima ljudi iz neolitske populacije sa lokaliteta Gomolava zapažene su promene na alveolarnoj kosti, koje su ukazivale na postojanje parodontopatije. Kod osam osoba je uočena resorpcija alveolarne kosti i eksponiranje korenova zuba i njhovih furkacija. Te resorpcije su se kretale od 3 do $7 \mathrm{~mm}$.

Nalazi vezani za status korenova zuba su veoma zanimljivi i zato su zahtevali posebnu pažnju. Prvi razlog za toliku pažnju je broj prisutnih korenova (28), koji je relativno visok i identičan broju izgubljenih zuba tokom života. Posebno kada se tome priključi i šest nalaza plitke i nezarasle alveole, koja ukazuje da su korenovi iz njih ispali neposredno pred smrt, ili, što je verovatnije, tek posle smrti. Drugi značajan razlog za njihovu analizu proističe iz činjenice da su kompletne krunice tih zuba razorene usled nekog patološkog procesa ili zaživotne traume. Nije retka situacija da se iznad zaostalih korenova mogu uočiti i periapikalni procesi. Analizom ovog osteološkog materijala 
ustanovljeno je da u vilicama osam osoba perzistira 28 radiksa, kao i još šest slučajeva kod kojih je koren izgubljen posle smrti individue. Iznad konstatovanih radiksa registrovano je pet periapeksnih promena (četiri 1. stepena i jedna 2. stepena). Etiološki faktor za nastanak ove patološke promene na $31 \mathrm{zubu}$ je najverovatnije abrazija, jer karijes na ostalim zubima nije bio prisutan, a okolni zubi su imali izraženu abraziju 3. i 4. stepena. U tri slučaja gubitak krunice bi mogao da se pripiše karijesu, jer su ostali zubi očuvani, sa niskim stepenom abrazije. U tom slučaju procenat karijesa za humanu populaciju sa Gomolave bi se sa $1,9 \%$ povećao na $3 \%$, što je i dalje ispod vrednosti koje je na sličnom uzorku ustanovila Zoffmann [12]. U njenim istraživanjima karijes se javlja u 3,7\%, što je znatno iznad prosečnih vrednosti za pojavu karijesa toga doba. Inače, karijes incidenca tokom trajanja neolita na području današnje Evrope se kretala u rasponu od 1,4\% do 3,2\%, što je u skladu sa našim nalazima za lokalitet Gomolava. Analizom zuba skeleta Đerdapske serije sa područja Đerdapske klisure ustanovljeno je da je karijesom bilo zahvaćeno 1,28\% zuba kod 3,76\% osoba iz neolitskog perioda Kulture Lepenskog Vira [15, 17, 19-22].

Dečji skeleti su pripadali uzrastu infans II, individualne starosti između 6 i 8 godina sa prisutnom mešovitom denticijom. Ustanovljeno je da su prikupljeni podaci pružali informacije o mlečnoj denticiji, pozicijama prvih i drugih stalnih molara i sekutića. Od stalne denticije kod obe individue bila su prisutna sva četiri prva molara, a kod jedne i dva zametka drugih molara u gornjoj vilici. Od stalnih zuba prisutno je bilo osam sekutića (pet gornjih i tri donja). Utvrđeno je da je u trenutku smrti bilo prisutno još sedam stalnih zuba, koji su najverovatnije izgubljeni tokom iskopavanja ili skladištenja. Svi stalni zubi su zdravi, bez karijesa, abrazije, naslaga, anomalija i bez promena u parodoncijumu (Tabela 2).

Od mlečne denticije bilo je prisutno 19 zuba (47\%) i to svi molari (16) i tri očnjaka. Preostala tri očnjaka su izgubljena posle smrti. Jedan mlečni sekutić je izgubljen tokom života, o čemu svedoči srasla alveola. Kod jedne osobe otkriven je karijes II klase, koji je zahvatao okluzalne i aproksimalne površine sva četiri gornja molara. Devet mlečnih zuba je bilo zahvaćeno abrazijom (pet 1. stepena, a četiri 2. stepena). Naslage na zubima, anomalije zuba i vilica, promene u parodoncijumu nisu ustanovljene (Tabela 3).

Dragocen je podatak da se iz današnje perspektive posle skoro osam milenijuma može pouzdano tvrditi da su dvoje dece iz perioda Vinčanske kulture imali potpuno očuvanu denticiju koja odgovara uzrastu u kome su se nalazili u trenutku smrti. Njihovi skeletni ostaci pokazuju da su imali sve mlečne molare i očnjake, po četiri stalna molara, jedan mlečni i 15 stalnih sekutića uz jedan i mlečni sekutić izgubljen tokom života, o čemu svedoči srasla alveola. Imali su abraziju na mlečnim zubima 1. i 2. stepena, i u jednom slučaju četiri karijesa II klase, srednje dubine (karijes medija).

\section{ZAKLJUČAK}

Uzimajući u obzir apsolutnu starost ispitivanih skeleta, prikupljeni podaci su izuzetno vredni po obimu građe i njenom sadržaju.

Pre skoro osam milenijuma humana populacija je imala dve denticije. Abrazija zuba je bila dominantna pojava i zahvatala je veliku većinu stalnih zuba. U dečjem uzrastu pojavljivala se u mešovitoj denticiji na mlečnim zubima. Od karijesa su obolevali stalni i mlečni zubi, u niskom procentu, tipičnom za taj period. Na gotovo polovini prisutnih zuba konstatovane su tvrde zubne naslage. Uočeni su i znaci parodontopatije i periapikalnih oboljenja.

\section{ZAHVALNOST}

Ljubaznošću gospode akademika Bogdana Bruknera i Borislava Jovanovića omogućen nam je uvid u građu i dokumentaciju za ovaj rad, na čemu im izražavamo najdublje poštovanje i zahvalnost. 